雪寒地域における冬季歩行環境の定量的評価 *

\title{
Quantitative Evaluation of Walking Environment in Winter for the Snowy Region
}

\author{
宮腰和弘 $* *$ 小林健一 $* * *$ 松本昌二**** \\ By Kazuhiro MIYAKOSHI, Kenichi KOBAYASHI, Shoji MATSUMOTO
}

\section{1. 研究の背景と目的}

雪寒地域における冬季の道路交通状況は、無雪地 域と違って、降積雪と除排雪の状況により大きな差 異がみられる。近年、道路交通の除排雪環境は、機 械除雪、消雪パイプ、流雪溝等の除排雪技術の発達、 及び各施設の普及によって飛躍的に改善されてきた 1)。それに伴って、他地域への移動や道路走行状態 において、住民は以前とは比較できない利便性・快 適性・安全性を得たと推察される。

しかし、冬季の自動車交通に対する除排雪レベル が向上したのに対して、冬季の歩行環境はほとんど 改善されていない。その原因は、歩行者の要求する サービス水準や歩行者意識に対する定量化が、未だ に十分考察されていないからである。除排雪がよ゙の レベルまで向上すれば、歩行者の何割が満足し、ど の程度評価が向上するのかについて、また降積雪に よる様々な状況の変化によって、どの程度評価が変 化するのかについて、数量的に把握されていないか らである。

そこで本研究では、歩行環境に着目して、冬季の 道路環境に対する地域住民の意識構造をアンケート 調査によって把握する。それによって意識面からみ た歩行環境の評価を行い、実際の歩行経路の選択行 動を検証し、降積雪などの気象状況の変化、道路の 除排雪レベルの変化に対応した地域住民の冬季歩行 環境を定量的に総合評価する。

\section{2. 評価方法とテータ}

歩行者の冬季における経路選択に関して、要因と しての意識構造は複雑で、その基準は多岐にわたる

\begin{tabular}{|c|c|c|}
\hline *キーワーズ & 除排雪 & 雪寒地域 \\
\hline **正会員 & 工博 & $\begin{array}{l}\text { 長岡工業高等専門学校 } \\
40 \text { 長岡市西片貝町888) }\end{array}$ \\
\hline ***正 & 工修 & 福井県 \\
\hline ****正会只 & 工博 & 套岡技， \\
\hline
\end{tabular}

と考えられる。また、歩行者の行う評価や判断は、 これまで定性的なものも含め共通の尺度がない。

そのため評価手法としては、複雑で多様な意識、 主観的な判断を定量化するために有効とされる、階 層構造分析法 (Analytic Hierarchy Process、AHP 手法）を適用し233)、以下の手順で検討する。

(1)対象となる問題（本研究では冬季における歩行 環境）を「利便性」「安全性」「快適性」の 3 評価 要素を軸に階層構造として分解する（図-1参照）。 この 3 評価要素の設定理由は、歩行者の欲求をどの 程度充足させているのかを評価するための定性的な 尺度として、最初に考えられる要素だからである。

(2)冬季歩行環境の階層構造に対して、AHP手法を 適用して各階層の要素間の重みづけを行う。重みづ けは、一対比較法による対象者へのアンケート調査 から求める。ただし、一対比較において首尾一貫し た答を期待することは不可能であるため、回答の整 合性をコンシステンシー指数C. I. で評価し、この值 が0.1以下（または0.15以下）なら有効とする。

(3)次に、最下層の各評価要素に対して冬季に考え られる様々な状態を段階ごとに数項目ずつ設定し、 それぞれの評価值」を求める（図-3 参照）。

この「評価値」を求めるために、「これ以上悪い 状態だと歩行に不満」と考えられる状態をアンケー 卜対象者に選択してもらい、その頻度の割合を一番 悪い状態から累積することにより（累積百分率）、 各状態において少なくとも全体の何\%の人が「この 程度の状態なら我慢して歩行できる」と判断してい るのかを算出する。この值は、ある意味では臨界点 としての満足度と考えられ、この值を各評価要素に 対する各状態の「評価值」と設定する。

(4)冬季において考えられる様々な歩行状態を、除 排雪施設を基本として、各道路ケースごとに設定す る (図-2 参照) ${ }^{4)}$ 。 


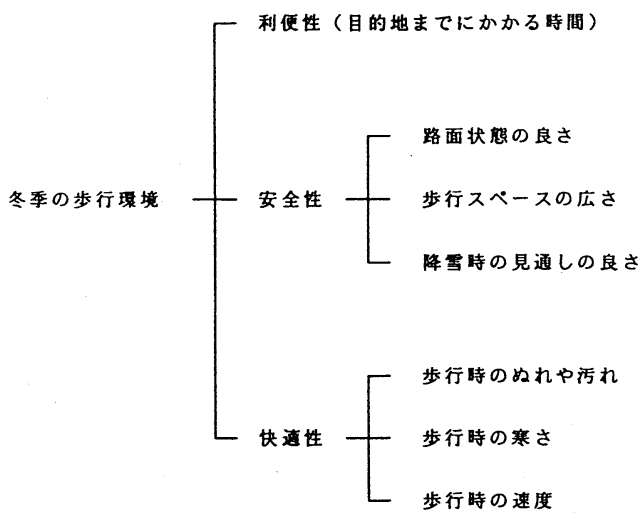

図-1 冬季歩行環境の階層構造図

このケース設定に対応する評価值に評価要素の重 みを掛け合わせることにより、各評価要素の得点を 求める。次に各評価要素の得点を合計することによ り、各道路リンクの総合評価「リンク得点」を算出 する（式(1)参照）。

$$
\mathrm{U}=\Sigma\left(\mathrm{W}_{1} \times \mathrm{P}_{1}\right)
$$

$$
\begin{aligned}
\text { ただし、 } \mathrm{L}: \text { 個人のリンク得点 } \\
\mathrm{W}_{1} \text { : 評価要素1の重み } \\
\mathrm{P}_{1} \text { : 評価要素1の評価值 }
\end{aligned}
$$

(5)得られたリンク得点を個人の地区内における実 際の冬季歩行経路に当てはめることにより、個人の 冬季歩行環境を定量的に示す「ルート得点!（式(2) 参照）を算出する。次いで、個人の冬季歩行行動 (ルート選択) をルート得点によって検証する。

$$
\mathrm{V}=\frac{\sum \mathrm{r}^{*}{ }_{\mathrm{i}} \cdot \mathrm{U}^{*}{ }_{\mathrm{i}}}{\sum \mathrm{r}^{*}{ }_{\mathrm{i}}}+\mathrm{Wc} \cdot \mathrm{Pc}
$$

ただし、V： 個人のルート得点

$\mathrm{U}^{*}{ }_{\mathrm{i}} \quad$ ：道路リンクiの得点（利便性を 除 $<$ )

$\mathrm{r}^{*}{ }_{\mathrm{i}} \quad$ ： 道路リンク $\mathrm{i} の$ 歩行距離

Wc : ルートCの利便性の重み

$\mathrm{PC}$ ：ルートCの利使性の評価值

対象地域は、豪雪地带であり克雪対策に積極的に

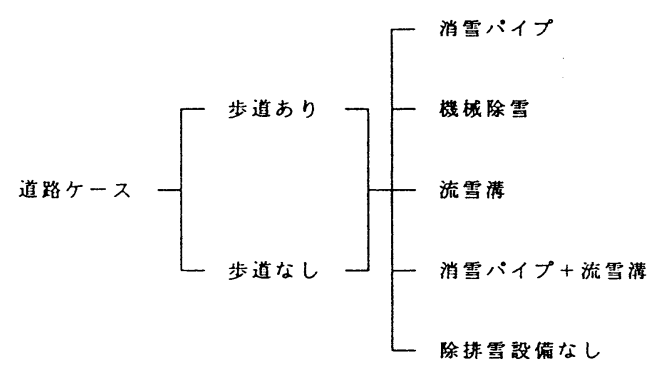

図-2 各道路ケースの設定構造図

取り組んでいる新潟県長岡市として、市内 16 町丁目 の住民、及び市役所の歩行通勤者を対象として冬季 歩行環境のアンケート調査を行った。調査内容は、 個人属性、歩行環境の重視度亡満足度、夏冬の歩行 経路等である。地域住民に対するアンケートは、配 布数 2,869部に対して回収数2,064部, 回収率 $71.9 \%$ になった。さらに, AHP手法の一対比較回答が矛盾 しているものや、無記入のものを省いた結果、有効 回収数 1,203 部、有効回収率 $41.9 \%$ になった。市役 所の歩行通勤者に対するアンケートは、回収数は 12 4 部、有効数は105部になった。

\section{3. リンク得点とルート得点の定量化}

\section{（1）重み、評価値の算出結果}

長岡市の地域住民に対する各評価要素の夏冬にお ける重みを表-1に示す（ただし、（）内は夏季の重

\begin{tabular}{|c|c|c|}
\hline 利 便 性 & （目的地までにかかる時間） & $0.183(0.239)$ \\
\hline \multirow{3}{*}{$\begin{array}{c}\text { 安 全 性 } \\
0.605 \\
(0.546)\end{array}$} & 路面状態の良さ & $0.310(0.188)$ \\
\hline & 歩行スペースの広さ & $0.154(0.182)$ \\
\hline & 降雪 (前方) 時の見通し & $0.141(0.176)$ \\
\hline \multirow{3}{*}{$\begin{array}{c}\text { 快 適 性 } \\
0.212 \\
(0.215)\end{array}$} & 歩行時のぬれや污れ & $0.137(0.118)$ \\
\hline & 歩行時の寒さ（気温） & $0.034(0.048)$ \\
\hline & 歩行時の速度 & $0.041(0.049)$ \\
\hline
\end{tabular}
み）。ここで、重みは各対象者ごとの重みを幾何平 均したものである。また、表-1では、各階層の上か ら重みを順に要素間の重みに従って分配することに

表-1 各評価要素の夏冬における相対的重み 
より、最終的な評価要素の重みを示す。なお、コン システンシー指数 C.I.は、いずれも C. I.<0.1で あり、データの有効性が確認された。

表-1から、夏冬の両方において「安全性」の重み が最も大きいことがわかる。また、最下層の評価要 素でみると、安全性の「路面状態の良さ」の重みが 最も大きく、快適性の中では「歩行時のぬれや污れ」 の重みが大きい。次いで夏と冬を比較すると、冬季 は評価要素ごとの重みの差が大きく、夏になると重 みが全体に均一化する傾向にある。これより、冬季 には重要視する要素が上述の 2つ（路面状態、塗れ や污れ）に集中することがわかる。

次に評価値の一例として、安全性の下位の評価要

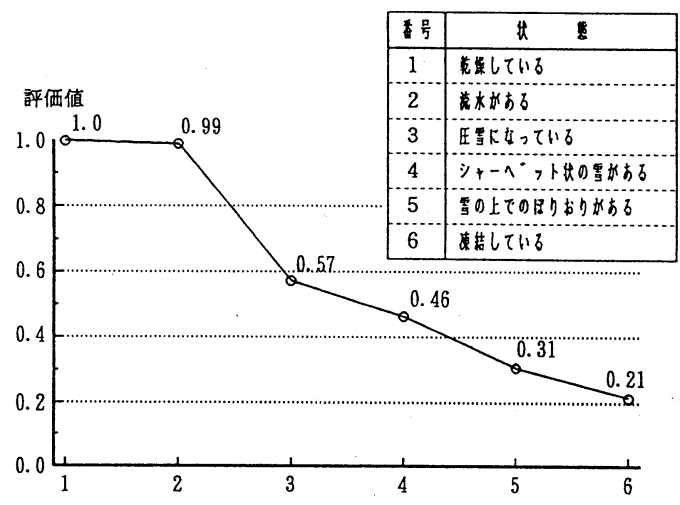

図-3 路面状態の評価值
素「路面状態の良さ」を図-3に示す。図-3において、 横軸は冬季の路面状態を段階的に設定したものであ り、縦軸は各状態の評価值である。「流水がある」 状態は「乾燥している」状態とほとんど変わらない 評価値だが、「圧雪になっている」状態では評価値 が大きく減少する。また「シャーベット状の雪があ る」状態になると0.5以下の評価值になってしまい、 大半の人が歩行に不満を感じることがわかる。

\section{（2）リンク得点の算出結果}

長岡市の地域住民を対象として、道路リンクの歩 行環境を評価する「リンク得点」を除排雪施設ごと に算出した（図-4参照）。リンク得点は、夏季の状 態を最高值の 100 点とし、0点を最低値としている。 設定した各道路ケースには、最も良い道路状態を示 した「最高得点」と最も悪い道路状態を示した「最 低得点」の 2 種類がある。

リンク得点の結果として、歩道があり消雪パイプ が設置されている道路ケースは、モデルケースの中 で最も得点が高く、最高得点では夏季の道路状態と ほとんど変わらない值を示している。

全てのケースに対してリンク得点幅の違いをみる と、歩道が設置されている場合は、消雪パイプが 約 50 点 100点、機械除雪が約 $30 \sim 70$ 点、流雪溝が 約50〜95点、消雪パイプ+流雪溝が約 60 点〜95点、

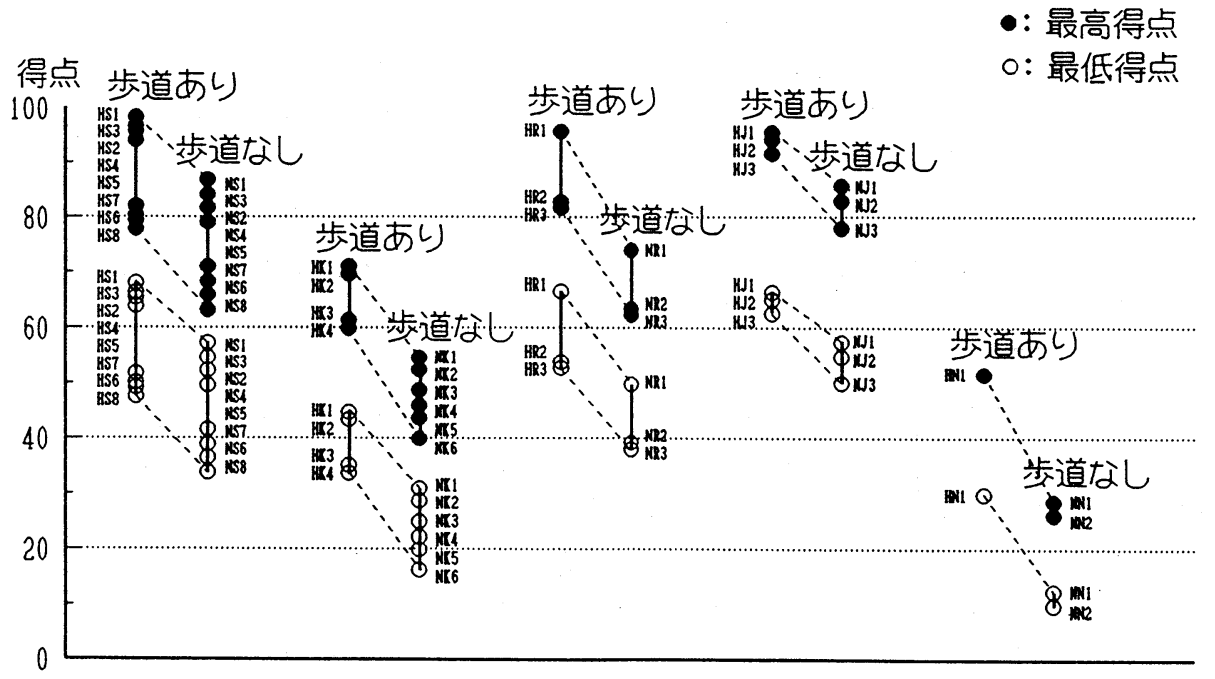

消雪パイプ 機械除雪 流雪溝 消雪パイ゚ 十流雪溝 除排雪設備なし

図-4 リンク得点（図中の記号は各ケースを示す） 
除排雪施設が無い状態だと約 30 ～50点となった。次 いで、歩道が設置されていない場合は、消雪パイプ が約 30 点〜85点、機械除雪が約 $15 \sim 55$ 点、流雪溝が 約 $40 \sim 75$ 点、消雪パイプ+流雪溝が約 $50 \sim 85$ 点、除 排雪施設が無い場合だと約10〜25点であった。

同一の除排雪施設の中で、道路ケースによってリ ンク得点の差が最も大きいのは消雪パイプの場合で あり、ケース間に約70点の開きがある。消雪パイプ といっても、道路状態の変化が激しく、得点が大き く変化することがわかる。一方、消雪パイプ+流雪 溝の場合、道路ケースによるリンク得点の差が小さ く、道路状態の変化が少なく、除排雪効果が安定し ていることがわかる。

また、歩道の存在の有無によって、各道路ケース とも約15～25点のリンク得点差が生じる。歩道がな い場合は、各道路ケースのリンク得点が分散しやす く、得点差が大きくなる傾向がみられる。

\section{（3）ルート得点の算出と検証}

（2）で得られた各道路ケースのリンク得点を個 人の実際の歩行経路に当てはめ、式(2)を用いて個 人の冬季歩行環境の総合評価である「ルート得点」 を算出した。なお、リンク得点は、各道路ケースの 総合評価のため、利便性の評価値である夏冬の歩行 時間差は、最良の状態と最悪の状態での評価しか示 せなかった。しかし、ルート得点では個人によって 歩行距離が異なるため、個人ごとに夏冬の歩行時間 差を設定した。

以上の設定に基づいて、目的地のバス停までの歩 行経路が夏冬で異なる対象者について、夏冬 2 ルー トの冬季におけるルート得点を地区別に示す（図 -5 参照)。

その結果、最高得点だと 46 人中全員が、冬の歩行 経路の方が夏の歩行経路よりルート得点が高く、最 低得点だと 46 人中 42 人 $(91 \%)$ が、冬の歩行経路の 方が夏の歩行経路よりルート得点が高くなった。す なわち、冬季での地区内歩行の場合、対象者はルー 卜得点のより大きい歩行経路に変更することが検証 された。

次に、個人が実際に歩行した経路の他に仮想経路 を設定して、ルート得点の検証を行った。方法とし ては、個人ごとに目的地までの仮想経路を 2 種類

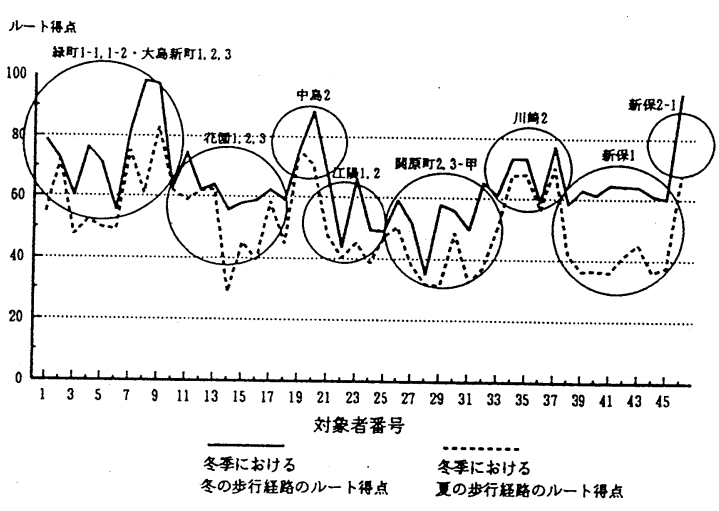

図-5 冬季歩行環境における夏冬経路のルート得点比較図

（場合によって 1 種類）設定し、ルート得点を求め た（図-6参照）。そして実際の歩行経路と仮想経路 のルート得点を比較して、実際の歩行経路の得点が 仮想経路より高い場合、歩行者は考えられる経路の 中で最も環境の優れた歩行経路を選択して通行して いることが実証される。

その結果、図-6のサンプルのように実際の歩行経 路のルート得点の方が仮想経路より高い対象者は、 地域住民において 90 人中 80 人で、89\%の的中率が得 られた。これにより、地区内通行において、ルート 得点は個人の冬季歩行環境を定量的に示すことが実 証された。

また、市役所通勤者の場合、実際の歩行経路にお けるルート得点が仮想経路より高い対象者は、84人 中57人となった。的中率は $68 \%$ で、地域住民の場合 より低くなった。ちなみに、目的地までの歩行距離 が $800 \mathrm{~m}$ 以内の対象者で比較した場合、19人中 14 人 で、的中率は74\%にまで上昇した。

\section{4. 地区の除排雪レベルの評価例}

個人のルート得点の式を応用して、アンケート調 查を行った 16 町丁目の除排雪レベルを定量的に示す 「地区得点」を算出した（図-7参照）。なお、図-7 では、隣接している町丁目に対して、住民相互の通 行があると考えられる地区ごとに結合している。

図-7の結果から、消雪パイプなどリンク得点の高 い施設が多く設置されている地区ほど、地区得点が 高いことがわかる。また、除排雪施設が無く地区得 


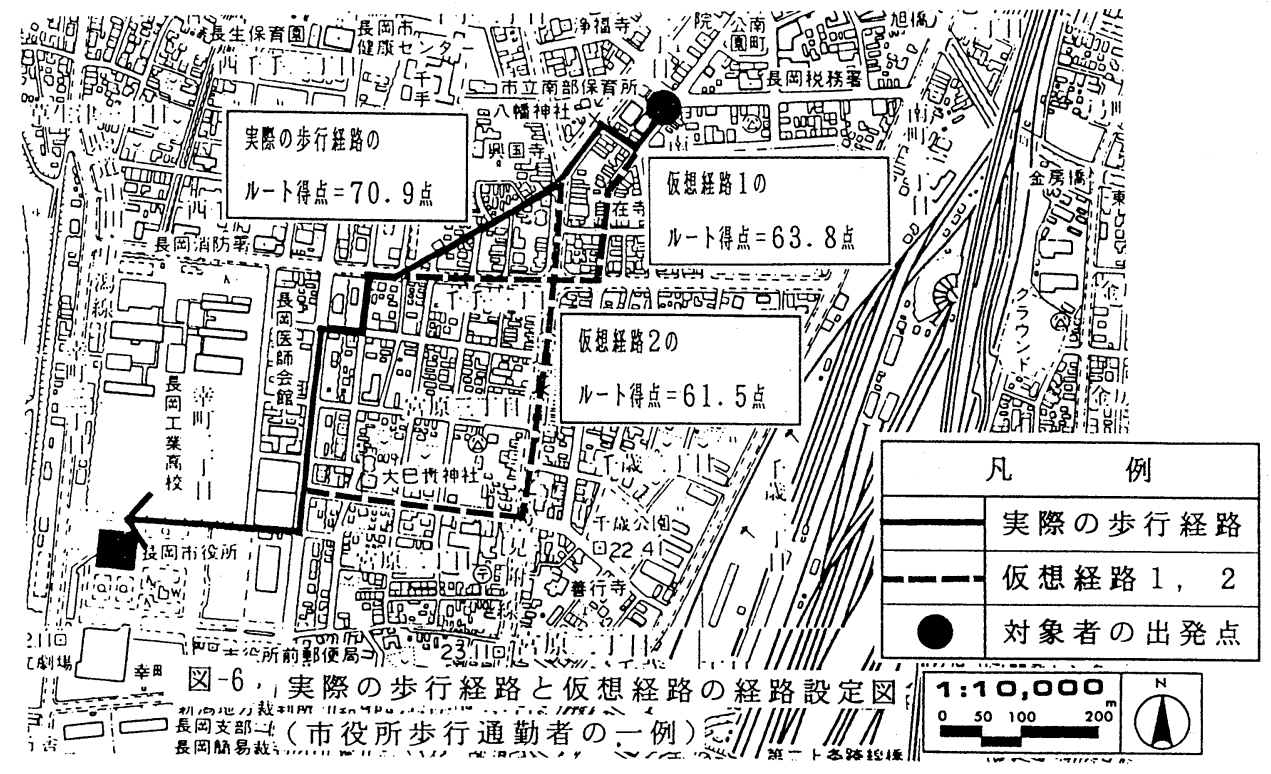

点の低い地区と比較して、地区間の差異が極めて大 きいことが判明した。

そこで、道路の除排雪施設を改善すれば、地区得 点、つまり地区の除排雪レベルがどのくらい向上す るのかを検討した。

例として関原地区のケースを示す（図-8参照）。 図-8において、グラフ横軸の番号 1 は現状の除排雪 レベルを示したもので、番号 2 以降は各種の改善ケ 一スを示している。なお、グラフ中の横線は、各評 価要素毎に 0.5 以上の評価值を抽出し、それに評価 要素の重みを掛け合わせることにより求めた「満足 できる得点ライン」を示したもので、満足得点は 66.

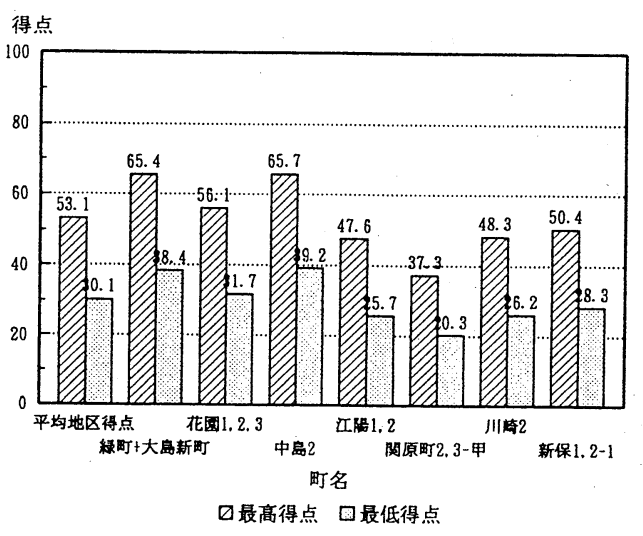

図-7 町丁目ごとの除排雪レベル
6点となった。

図-8によれば、番号 1 の現状の除排雪レベルでは、 満足できる得点ラインより点数がかなり下回ってお り、歩行者は現状の歩行環境に満足していないこと がわかった。また、改善ケースにおいては番号 2 ， 3 では 30 点以上、番号 4,5 では 45 点以上、得点が 増加し、大幅に除排雪レベルが向上する。今後、道 路及び除排雪施設の整備を行う際には、歩行者の評 価する除排雪レベルがどれだけ向上し、他地区との 差異がどれだけ小さくなるかを考慮する必要がある と考える。

\section{5. 結論}

以上から本研究では、以下のことが判明した。 (1)地区内交通の場合、歩行者は冬季の歩行環境、特 に安全性を重要視して通行している。

(2)冬季の道路リンクの歩行状態についての総合評価 である「リンク得点」によって、除排雪の効果を定 量化できる。

(3)冬季の降雪時における歩行環境の評価は、「ルー 卜得点」によって定量的に表示できる。

(4)冬季において除排雪施設の整備された「ルート得 点」の高い経路を、歩行者は選択して通行している ことが検証された。

(5)ルート得点と交通行動との適合性により、結果的 


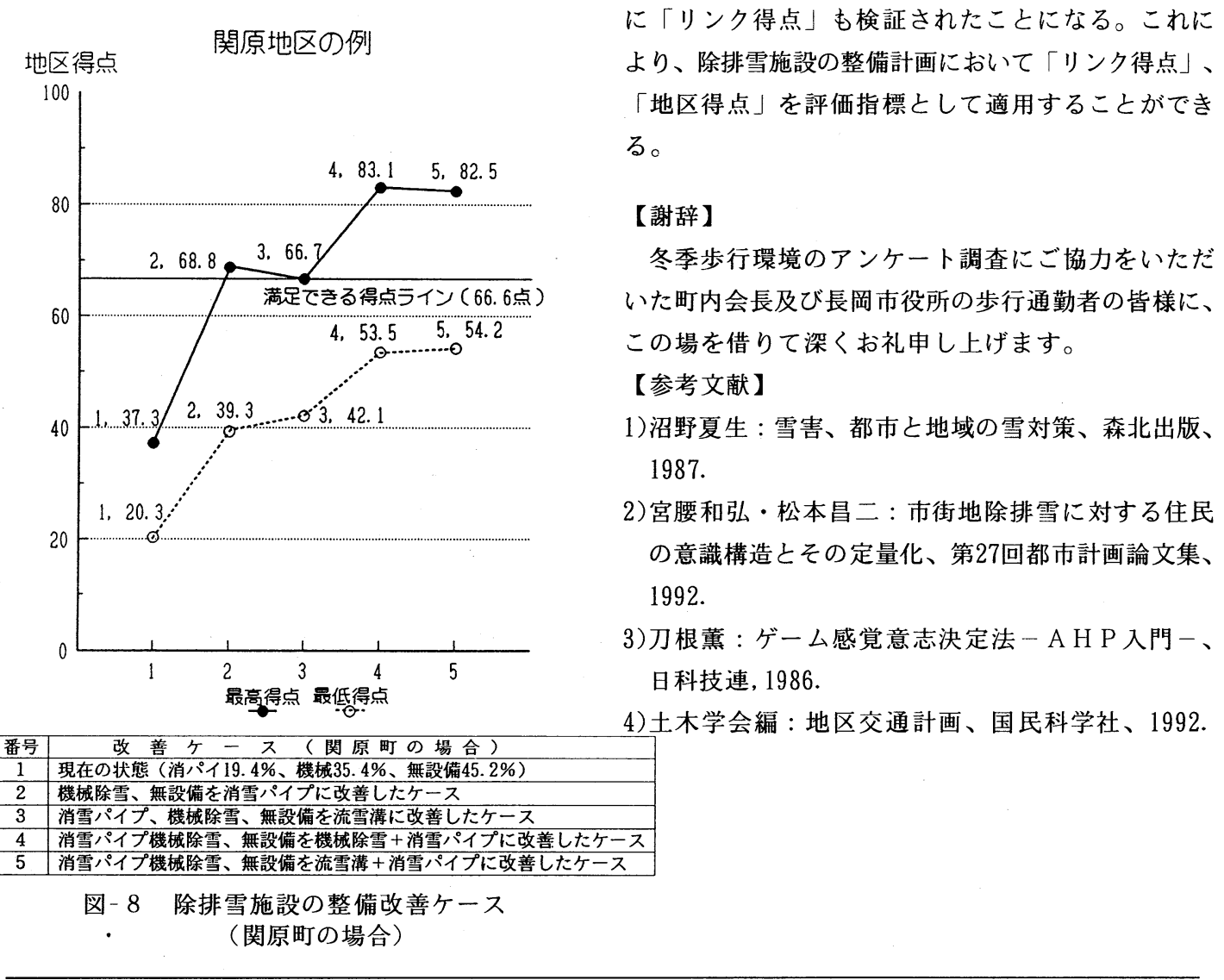

雪寒地域における冬季歩行環境の定量的評価

宮腰和弘・小林健一・松本昌二

本研究は、冬季における道路歩行環境に対する地域住民の意識構造を把握し、意識面からみた歩行環 境を定量的に評価することを目的としている。長岡市を対象として、冬季歩行環境のアンケート調查 を実施し、デー夕を収集した。評価手法としては階層構造分析法（A H P 法）を使用した。デー夕分 析により、冬季における各道路リンクの歩行環境を「リンク得点」として定量的に評価することがで きた。その結果、除排雪施設の整備計画において「リンク得点」、「地区得点」を評価指標として適 用することができる。

Quantitative Evaluation of Walking Environment in Winter for the Snowy Region

By Kazuhiro MIYAKOSHI, Kenichi KOBAYASHI, and Shoji MATSUMOTO

The objectives of this paper are to identify the hierarchical structure of inhabitants' consciousness toward walking environment in winter and quantitatively evaluate their preference by applying the method of Analytical Hierarchy Process (AHP). The survey was carried out in urban areas of Nagaoka. Walking environment of roads can be measured by "a link score" and "a route score", which are mainly dependent on the types of snow removal systemes. The route scores of roads are empirically tested by the route choice behaviour of walkers in winter. 